\title{
Knowledge and Morality of School-Age Children and Adolescents Regarding Environmental Issues and Moral Dilemmas
}

\author{
Carla Luciane Blum Vestena1, Fernanda Hellen Ribeiro Piske ${ }^{2}$ \\ ${ }^{1}$ Unicentro, Guarapuava, Brazil \\ ${ }^{2}$ Federal University of Parana, Curitiba, Brazil \\ Email: nandahellen@hotmail.com
}

How to cite this paper: Vestena, C. L. B., \& Piske, F. H. R. (2017). Knowledge and Morality of School-Age Children and Adolescents Regarding Environmental Issues and Moral Dilemmas. Creative Education, $8,177-188$

https://doi.org/10.4236/ce.2017.82015

Received: September 16, 2016

Accepted: February 1, 2017

Published: February 4, 2017

Copyright $\odot 2017$ by authors and Scientific Research Publishing Inc. This work is licensed under the Creative Commons Attribution International License (CC BY 4.0).

http://creativecommons.org/licenses/by/4.0/

\begin{abstract}
A research gap exists with regard to the analysis of school children and adolescents' awareness on environmental issues. Current investigation analyzes data of 240 children and adolescents, aged between 8 and 14 years, within different school contexts in the mid-southern region of Brazil, on their knowledge level and moral judgment on solid wastes, river water and tree life. Whereas the exploratory research with different groups of different ages verifies the manner behavior emerges and changes, the transversal design gives an evolution aspect of data through the examination of a great number of agents. Results showed that children and adolescents have similar knowledge on the environment within different school contexts, except differences at environmental knowledge level. The latter revealed a mild broadening trend in proportion to the $8-14$ years age bracket. Environmental moral judgment varied a lot, regardless of the agents' age, and failed to be related to the knowledge that children and adolescents had on the environmental themes. Schools featuring well-defined pedagogical proposals were positively salient among the others. Environmental knowledge and moral judgment on environmental issues are not determining but implied chiefly as from the age of eleven, since both are the result of the agents' social interactivity within the environment and basically require affectivity and cooperation.
\end{abstract}

\section{Keywords}

Piaget, Socio-Environmental Knowledge, Moral Judgement

\section{Introduction}

Environmental issues are a worldwide fact to be taken into consideration in contemporary society, since they affect quality of life on our planet. Despite 
environmental warnings given since the 1960s, the proposal for sustainable development especially following the Rio-92 Summit has shown itself to still be ambiguous with regard to justice to reduce social inequalities and overcome socio-environmental problems within and between countries.

As such, following the Stockholm event, environmental education has been highlighted as strategic and a priority in preparing for citizenship that includes socio-environmental values. In Brazil the current National Curricular Guidelines on Environmental Education (Brasil, 2012) reaffirm that socio-environmental issues must be part of initial and ongoing teacher training curricula, as also determined by the Environmental Education Policy (Brasil, 1999) and the Official Gazette of the Federal Republic of Brazil (Brasil, 2002).

Research into students' perception of environmental problems has shown the existence of children who did not know the real physical conditions of local natural elements, even though they take part in Environmental Education projects in Brazil's schools. Data analysed by the Organization for Economic Cooperation and Development OECD (2009) showed that teenagers born in the 1990s in Brazil had a knowledge deficit in relation to environmental issues.

Studies have shown that few teachers teach Environmental Education, that they are unaware of how children and adolescents acquire knowledge and that they give little value to the role of social interactions in the learning process.

There is a shortage of research analysing the awareness and morality of school-age children and adolescents regarding environmental issues.

This article presents the analysis of data on 240 children and adolescents aged between eight and fourteen, from different school settings in South Central Brazil, as to their level of knowledge and moral judgement about solid waste, river water and tree life.

\section{Methods}

This is an exploratory study of different groups of subjects of different ages, undertaken between 2006 and 2010, to observe how conducts appear and change. A cross-sectional design was adopted because it enables a view to be obtained of evolutionary data in a short space of time as well as enabling a large number of subjects to be studied.

The interviews undertaken are based on research themes defined by means of observations conducted in 2008 and 2009, involving the accompaniment of students in each grade during Environmental Education activities, during in-school activities (lessons) and out-of-school activities (trips, cinema, visits).

The interviews took place in 2009 and lasted between 12 and 30 minutes depending on the age of the children and adolescents. The list of questions and moral dilemmas was validated by means of a pilot study performed with two subjects aged 8, two aged 11 and two aged 14 from schools B1 and B2, following their parents' informed consent.

The total sample of subjects was comprised of 240 school children attending $3^{\text {rd }}$ to $8^{\text {th }}$ grade and aged 8 to 14 , distributed homogeneously and of both sexes. 
The number of subjects was determined by the criteria indicated above and by the need to consider ten subjects per age group, as per Delval (2002: p. 102), whereby "ten subjects is an adequate number for each age group. It is difficult to reach conclusions with a smaller number of subjects, whilst with a large number analysis is harder".

We selected two public schools not pertaining to any religion and three private schools, one of which pertained to a religion whilst the others did not. We attributed a pseudonym to each one of the five schools in order to maintain their identity confidential, as per Table 1.

The schools selected were basically located in the municipality of Guarapuava, in the south central region of the state of Paraná, as well as one private school in the municipality of Itapira, in the eastern region of the state of São Paulo. One of the private schools (school D) selected in Guarapuava pertained to a religion, whilst the other (school C) did not.

We sorted the data on environmental knowledge in ascending order according to the age of the 240 subjects studied. Moral judgement of environmental issues was assessed based on the respect shown by the children and adolescents with regard to environment-related moral dilemmas. The judgement made by each of the students was classified in accordance with the analysis categories adopted, namely: Moral Judgement in Respect or in Disrespect of the Environment.

\section{Results and Discussion}

\section{1) Children and adolescents' level of knowledge}

The results indicated that both the children and the adolescents in the different school settings have similar environmental knowledge. The only difference in the level of environmental knowledge was a moderate tendency to increased knowledge as age increased, from eight to fourteen years old.

A significant number of children and adolescents showed a discrepancy from the general tendency, according to the different levels of development, both

Table 1. Principal characteristics of the selected schools.

\begin{tabular}{|c|c|}
\hline School & PRINCIPAL CHARACTERISTICS \\
\hline A & $\begin{array}{l}\text { Private. Not pertaining to any religion. Infant, Primary and Middle School Education }\left(1^{\text {st }} \text { to } 8^{\text {th }} \text { grade). Has a well-defined }\right. \\
\text { teaching concept, }{ }^{*} \text { based on Piagetian studies. Does not use handouts and textbooks. Located in the town of Itapira/SP. }\end{array}$ \\
\hline B1 & $\begin{array}{l}\text { Public. Municipal. Not pertaining to any religion. Infant and Primary School Education ( } 1^{\text {st }} \text { to } 4^{\text {th }} \text { grade). Does not have a } \\
\text { well-defined teaching concept. Uses textbooks. Located on the outskirts of the town of Guarapuava/PR. }\end{array}$ \\
\hline B2 & $\begin{array}{l}\text { Public. State-level. Not pertaining to any religion. Middle School Education }\left(5^{\text {th }} \text { to } 8^{\text {th }} \text { grade). Does not have a well-defined }\right. \\
\text { teaching concept. Uses textbooks. Located in the town of Guarapuava/PR. }\end{array}$ \\
\hline $\mathrm{C}$ & $\begin{array}{l}\text { Private. Not pertaining to any religion. Infant, Primary and Middle School Education }\left(1^{\text {st }} \text { to } 8^{\text {th }} \text { grade }\right) \text { and Sixth Form }\left(1^{\text {st }} \text { to } 3^{\text {rd }}\right. \\
\text { grade). Does not have a well-defined teaching concept. Uses textbooks. Located in the town of Guarapuava/PR. }\end{array}$ \\
\hline D & $\begin{array}{l}\text { Private. Pertaining to a religion-Roman Catholic. Infant, Primary and Middle School Education ( } 1^{\text {st }} \text { to } 8^{\text {th }} \text { grade) and Sixth Form } \\
\left(1^{\text {st }} \text { to } 3^{\text {rd }} \text { grade). Does not have a well-defined teaching concept. Uses textbooks. Located in the town of Guarapuava/PR. }\right.\end{array}$ \\
\hline
\end{tabular}

${ }^{\star}$ A defined teaching concept is understood to mean a school that organizes what it teaches based on a theoretical reference. 
greater and lesser, such as, for example, children aged thirteen and fourteen with only preliminary knowledge of environmental issues (Figure 1).

Preliminary Environmental Knowledge occurred mainly in children aged between eight to ten and eleven years old. For example, predominant knowledge about residual waste is hermetic, i.e. it is limited to isolated phases and to distinguishing objects. There is no understanding of the systemic process of the decomposition of solid waste disposed of in inappropriate places, nor of the specific decomposition characteristics of each type of matter (food, paper, PET and glass bottles (Table 2).

Students with preliminary environmental knowledge have no specific knowledge about trees, their importance, social and ecological function. Trees appear to be an element in isolation from the rest of nature's elements. The students think that rivers are polluted because they notice solid wastes on their banks and the foul smell, but they are unaware of the real causes of pollution and its effects on the health of human beings and other living beings (Figure 2).

A large number of children aged eight to ten had preliminary environmental knowledge about the process of matter transformation. Moreover, there is initial elaboration of concepts of environmental issues, whereby the process is more advanced in students aged ten, eleven and thirteen when compared to those aged eight to ten, as in general the former have systemic knowledge about one of the issues studied.

With regard to Preliminary Environmental Knowledge, the children do not show complete structures of systemic knowledge, as they have restricted knowledge

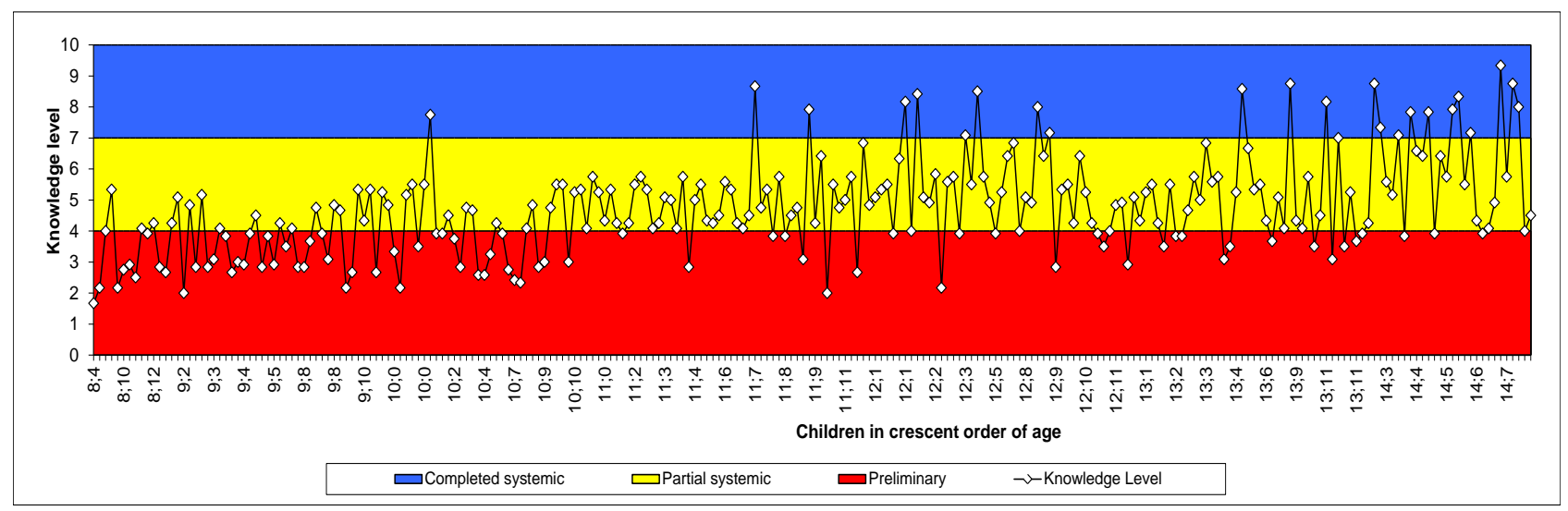

Figure 1. Children and adolescent's environmental knowledge.

Table 2. Types of environmental knowledge by age group.

\begin{tabular}{ccccccccc}
\hline & \multicolumn{7}{c}{ ENVIRONMENTAL KNOWLEDGE } \\
\cline { 2 - 9 } Age & \multicolumn{2}{c}{ Preliminary } & \multicolumn{2}{c}{ Partial Systemic } & \multicolumn{2}{c}{ Complete Systemic } & \multicolumn{2}{c}{ TOTAL } \\
\cline { 2 - 9 } & Frequency & $\%$ & Frequency & $\%$ & Frequency & $\%$ & Frequency & $\%$ \\
\hline $8-10$ years & 48 & 56.5 & 36 & 42.4 & 1 & 1.2 & 85 & 100 \\
$11-12$ years & 17 & 19.8 & 61 & 70.9 & 8 & 9.3 & 86 & 100 \\
$13-14$ years & 15 & 21.7 & 39 & 56.5 & 15 & 21.7 & 69 & 100 \\
\hline
\end{tabular}




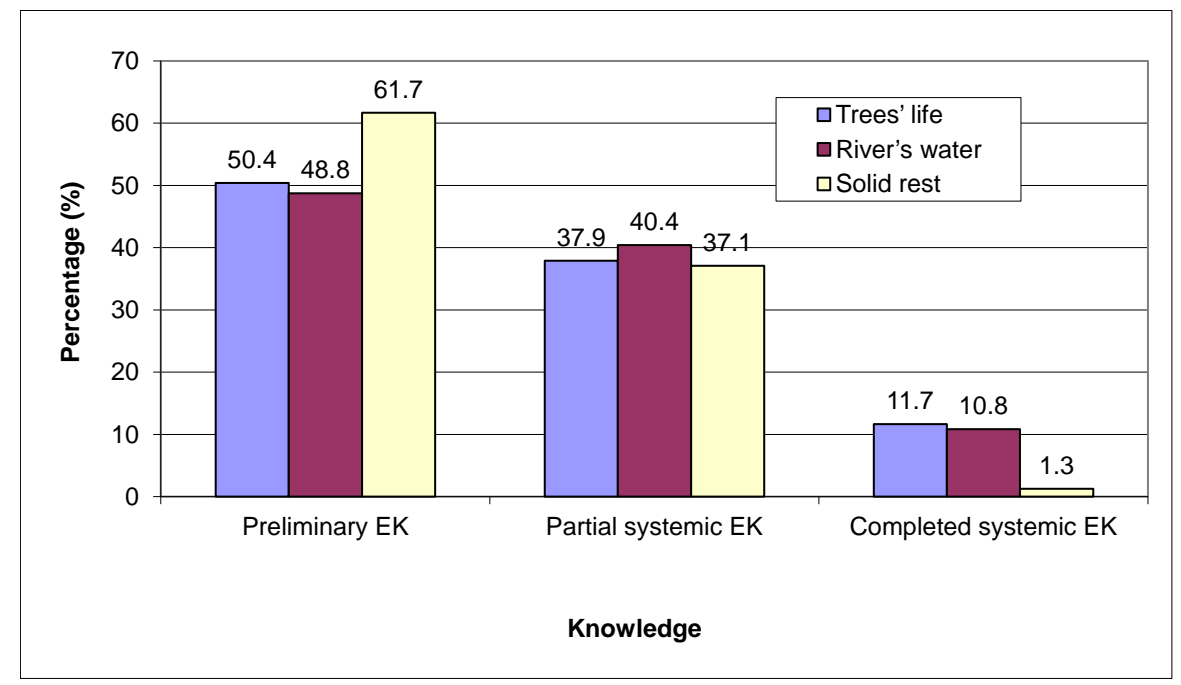

Figure 2. Children and adolescents: types of environmental knowledge.

regarding objects. For example, in relation to plastic bottles, they are unable to say where they came from, what their use is and how they decompose. Taking the example further, with regard to two questions about decomposition: (1) if two bottles of the same shape and size, one plastic and the other glass, are thrown onto wasteland, which of them will decompose first? (2) there are two bottles of the same size but different shapes, and the plastic bottle keeps its shape but the glass bottle breaks into little pieces, which bottle decomposes first? When answering these questions, the majority of the children and adolescents state that the plastic bottle will decompose first when the two bottles have the same shape, but that the glass bottle will decompose first when the bottles have different shapes (broken glass bottle). This allows us to affirm that they take shape into consideration and not matter. They still see things in an atomistic manner. This is explained because of the number of students with preliminary environmental knowledge about the environment. The following statement by one of the children exemplifies this fact:

- Which bottle decomposes quickest on a plot of wasteland, a plastic one or a glass one?

Imagine that we have two bottles, a plastic one and another just the same but made of glass. Which bottle will break down first? Hum, er, er, I think it's the plastic one.

- Why? Because glass only breaks down if it's thrown and breaks into pieces. I think that glass will take many years, although the plastic bottle will too, but I think glass is more resistant.

- And what if a complete plastic bottle and a broken glass bottle were thrown onto a plot of wasteland. Which do you think would decompose the quickest? This time I think it's the one that's broken down (referring to the glass) because there are fewer pieces in the environment for it (referring to the bottle) to break down. The smaller it is the easier it is to break down.

A. $22(11 ; 3)$ 
In this case, children are in a process of elaborating the notion of substance, because it affirms that the conservation of the substance occurs in an intuitive manner, as it is based on empirical data and not on operational composition, as Piaget (1978) mentions.

The children and adolescents who showed Preliminary Environmental Knowledge are basically at the stage of developing Concrete Operational knowledge. To a certain extent the development of knowledge about environmental issues occurred late in relation to the development of intelligence analysed by Piaget (1983), as it is conceived that Preliminary Environmental Knowledge about environmental issues could coincide with the beginning of the Concrete Operational stage and Partial Systemic and Systemic Environmental Knowledge could coincide with the Formal Operational stage. However, the level of development (competence) does not necessarily coincide with knowledge (exercising).

Partial Systemic Environmental Knowledge appeared with effect from ten to eleven years of age until fourteen to fifteen. In this phase, knowledge is partitioned, sometimes in relation to a given theme, when the student shows understanding of the environmental system and of causes and consequences of actions on the environment, sometimes when the student does not know what the impacts of the actions are and/or devises false hypothesis as to the causes and consequences. Partial systemic knowledge is situated between preliminary and complete systemic knowledge and is understood to be something that is in the process of developing.

Children and adolescents with Systemic Environmental Knowledge showed that they understood the relationships between the elements of the environmental system, the causes and consequences of human interventions and their impact on the lives of living beings.

The inadequate disposal of solid waste is totally understood as causing alterations in the environment that affect the quality of natural resources and human health. The water cycle is influenced both quantitatively and qualitatively by interventions of a human nature. The movement of water on, under and above the earth's surface determines how substances are transported, such as: sediments, solid waste, effluents, etc., located on the drained area and which extrapolate the river's course. As such, alterations to the drainage area can generate impacts on the dynamics of the fluvial processes and on the quality and quantity of water, having impacts on practically all the components of the environmental system.

This level of environmental knowledge can be justified when a child coordinates the various schemas devised as the body assimilates the milieu, there being a relationship between the milieu and the body (exchanges). Thought categories undergo transformism and there is increasingly elaborate adaptation of thoughts about the elements of nature, as well as adaptation of these elements to thoughts, in accordance with Parrat-Dayan's view (2000) that in the domain of knowledge there is a notion of the transformism of thought categories.

In short, we found that in the thirteen to fourteen age group only $21.4 \%$ of the 
adolescents showed Systemic Knowledge and the majority showed Partial Systemic Knowledge (56.5\%).

A possible reasoning within knowledge about environmental issues is retarded in relation to the phases of development. These phases can be explained by the fact that in order to have systemic knowledge children and adolescents need to have operational structures that comprehend reversibility, mobility and transformations between (physical) states. This is only possible when they distinguish infralogical operations, i.e. physical operations and operations in space and time, as well as logical and mathematical operations. Infralogical operations have a bearing on positions and states and express, therefore, the transformations of objects, rather than leaving this Constant (Piaget, 1979).

\section{2) Children and adolescents' level of moral judgement of environmental impacts}

We noted that the students, from eleven years onwards, although principally the older ones, demonstrated a more significant level in disrespect of the environment than younger children and adolescents aged eight to eleven (Figure 3).

In general, Moral Judgement (MJ) in Respect of the Environment was predominant in $83.3 \%$ of the environmental dilemmas, whilst MJ in Disrespect of the Environment was $16.7 \%$. When assessing $M J$ incidence in relation to the different themes, it was found to be homogeneous, with slightly more MJ in Respect of the Environment for the dilemma of inadequate disposal of solid waste and slightly more $\mathrm{MJ}$ in Disrespect of the Environment for polluted waters (Figure 4).

Moral Judgements in Disrespect of the Environment increased in the thirteen to fourteen age group, to the detriment of MJ in Respect, which has to be associated with moral development itself (Table 3 ).

The considerable presence of subjects in the MJ Environmental Respect/Disrespect category (31.9\%) has to be associated with the affectivity they demonstrate during conflict situations (dilemma) involving elements to which they attribute value; for example, the need for a family member to have a job. In this case, when a child is asked about whether or not a factory should be built,

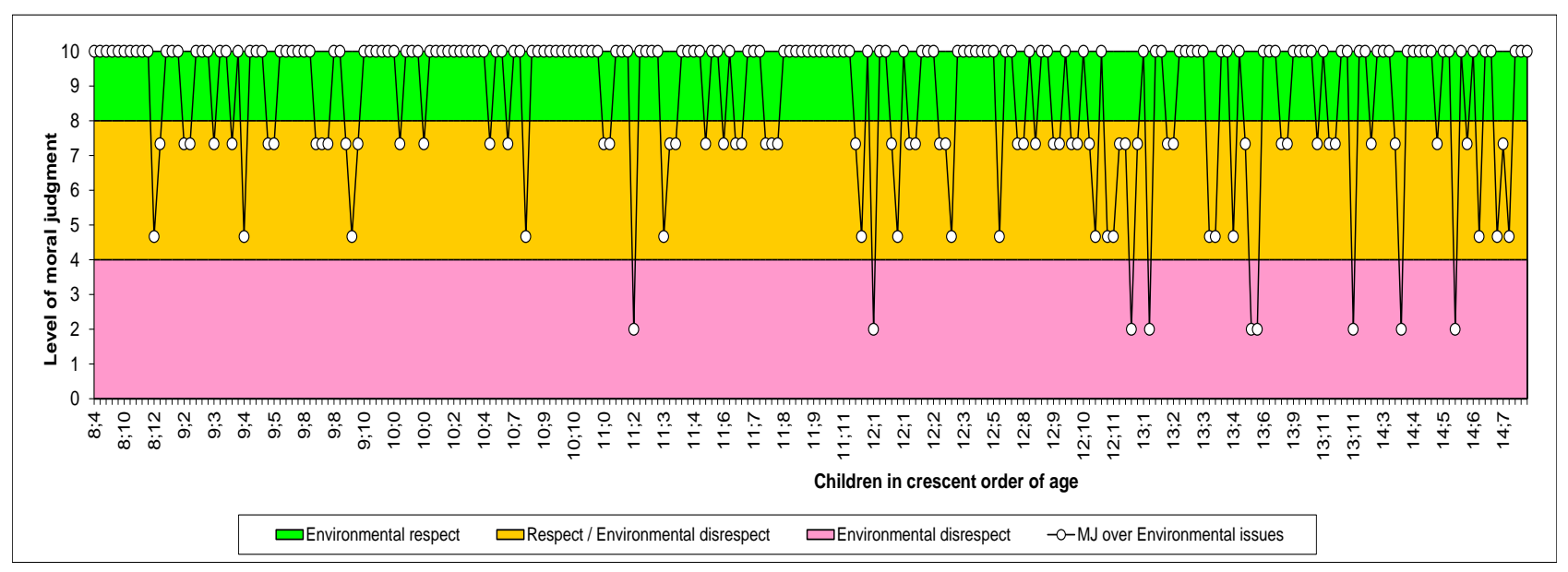

Figure 3. Types of environmental moral judgements. 


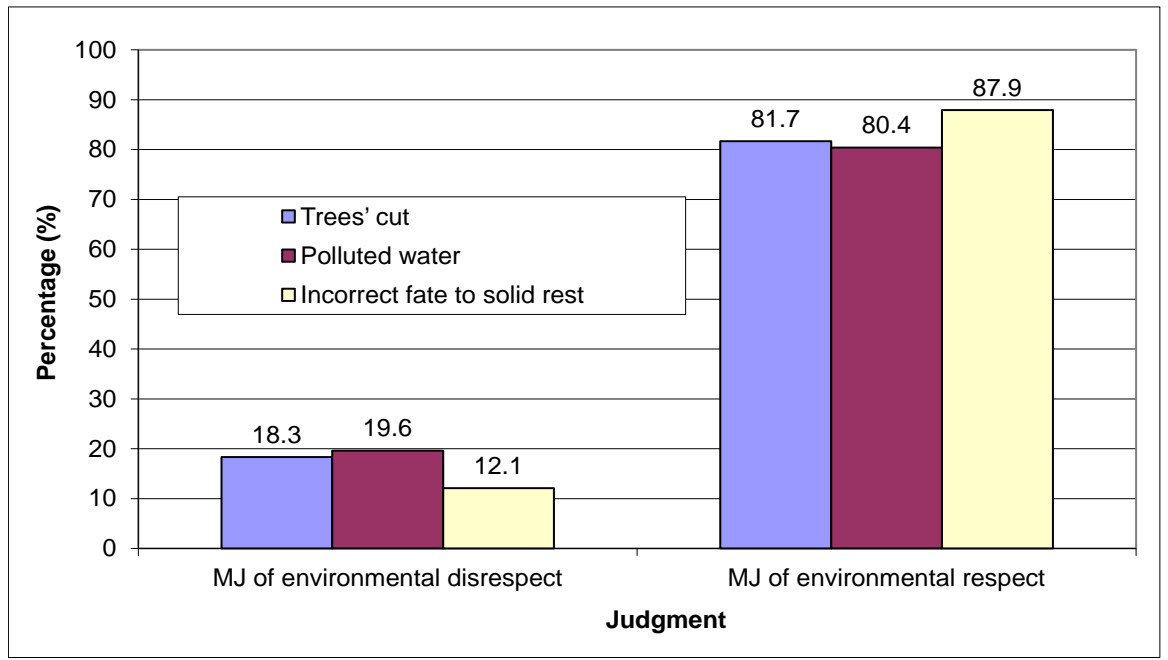

Figure 4. Children and adolescents' types of environmental moral judgement.

Table 3. Types of environmental MJ by age group.

\begin{tabular}{ccccccccc}
\hline & \multicolumn{6}{c}{ MORAL JUDGEMENT OF ENVIRONMENTAL ISSUES } \\
\cline { 2 - 9 } Age & $\begin{array}{c}\text { Environmental } \\
\text { Respect }\end{array}$ & $\begin{array}{c}\text { Environmental } \\
\text { Respect/Disrespect }\end{array}$ & $\begin{array}{c}\text { Environmental } \\
\text { Disrespect }\end{array}$ & \multicolumn{2}{c}{ TOTAL } \\
\cline { 2 - 9 } & Frequency & $\%$ & Frequency & $\%$ & Frequency & $\%$ & Frequency & $\%$ \\
\hline $8-10$ years & 65 & 76.5 & 20 & 23.5 & 0 & 0.0 & 85 & 100 \\
$11-12$ years & 51 & 59.3 & 33 & 38.4 & 2 & 2.3 & 86 & 100 \\
$13-14$ years & 40 & 58.0 & 22 & 31.9 & 7 & 10.1 & 69 & 100 \\
\hline
\end{tabular}

which would generate employment but would pollute the river, the child gives a moral judgement in favour of building the factory because this is the most outstanding need, even though the pollution of the water would affect many people.

The occurrence of indices of Moral Judgement in Disrespect of the Environment in relation to the issue of tree felling, at School B1, may be associated with the reality faced by the children and adolescents at this school. It has no sports ground for Physical Education lessons and this may have influenced the students' Moral Judgement in Disrespect of the Environment.

We found the best indices of Moral Judgement in Respect of the Environment at Schools D and A. We noted that conflicts between students at School A are discussed by the teachers and by the class in the form of specific meetings. Teachers do not use expiatory punishments as they believe that punishing students does not alter their behaviour regarding environmental issues. This may be contributing to the existence of cooperation and, consequently, to mutual respect, as it requires reciprocity and principals of justice. This behaviour can be explained by the operational teaching concept developed at the school, as the teachers and their teaching practices were seen to promote cooperative environments which enable students to develop autonomy right from the first years of primary education. This explains the presence of high indices of Moral Judgement in Respect of the Environment. 
At School D it was evident that almost all children aged under eleven demonstrated Moral Judgement in Respect of the Environment. This is probably related to the relationship of interindividual coercion or the children's egocentricity, propagated by the heteronomous phase and made possible through unilateral respect.

In this school, as already mentioned, there are constant activities aimed at developing human values based on Christian principles. This would explain the results found.

Another relevant aspect to be highlighted is that despite School D having a philosophical concept of a religious nature, the Judeao-Christian conception of the world was made evident in the following words of one of the subjects interviewed:

- When you think about trees, do you think they have life? Yes.

- Why? Because God created trees and they increase in size, they grow just

like we do. D.15 (10;2)

The divine explanation of the creation of nature is referred to very little by the children when analysing the issue of trees, although the understanding of the world based on religious knowledge may have explained nature as God's creation and as a pure and perfect work, as stated by Brailovsky (1992).

In keeping with Piaget (1977: p. 313), building rules through mutual agreement and cooperation becomes rooted within the child's conscience and leads to an effective practice, as cooperation constitutes "the system of interindividual operations", i.e., the operational clusterings that enable individuals' operations to adjust to each other. Individual operations "constitute the uncentred actions susceptible to coordinating themselves into clusters that encompass other people's operations", as well as one's own operations.

It is also appropriate to say that this oscillation, which may be the result of the process of moral development in relation to environmental issues, could be an intermediate and imbalanced stage between heteronomy and autonomy. Values operating with heteronomy are conditioned by agents that exert coercion and environmental moral judgement is determined by this context. However, when children and adolescents evolve and attain autonomy, they judge based on values.

Heteronomous children may demonstrate both environmental respect and disrespect, owing to the imposition caused by coercion made possible by unilateral respect (regardless of their parents' wishes). Contrary to this, there are children who despite building very clear moral rules in relation to the environment, in certain situations, such as at school, they are not coerced by the teacher because he or she does not exert authority. As such, they tend to disrespect rules and not respect the environment, regardless of whether the teacher is present or absent. This occurs owing to the phase of transition from heteronomy to autonomy when children begin to reflect about social rules and no longer simply comply with them. This is why when they are in a coercive environment where 
rules are imposed, they tend not to obey them because they are beginning to coordinate their own points of view.

We agree with Piaget (1973: p. 108) that conditions of equilibrium result in the constitution of a form of logic only in certain types of exchange which can be defined from the term of cooperation, being the opposite to exchanges diverted by a factor, whether this be egocentricity or coercion. As such, "equilibrium cannot be achieved when, owing to intellectual egocentricity, the partners are not able to coordinate their points of view". This is also related to cooperation with the environment and nature.

\section{Conclusion}

The environmental knowledge of the children and adolescents, in general, is preliminary and intermediate, i.e. they do not have systematized understandings of the interrelations between the elements of the environmental system and many of them do not demonstrate knowledge of the constitution of different types of matter present in the environment.

The majority of the children and adolescents studied show moral judgement in respect of environmental themes, as well as cases of moral judgement in disrespect of the environment regardless of their age.

The environmental knowledge of the children and adolescents, differently to their environmental moral judgement, showed a moderate tendency to increasing as they became older, between eight and fourteen years old.

Moral Judgement in Respect of the Environment is extremely social, since children and adolescents need to understand the environmental system as an integrated totality and that actions in the milieu cause changes in the environment. The notion of cooperation is fundamental in relation to the environment, since thinking about the environment means thinking about collectivity.

Despite environmental knowledge and Moral Judgement about environmental issues not being determinants, they are implied, principally from eleven years of age onwards, given that both result from the social interaction of individuals in the environment.

As such, we can affirm that social factors, including the transmission of education (family and school context), and social interaction impose respect for the environment as rules to be obeyed. These rules are reinforced in environmental education practices. In this way, in general, heteronomous children express moral judgements in respect of the environment.

We believe that not always what children think correct is what they would do in real situation. Therefore, the results of Environmental Moral Judgment presented in this paper should be used only as an indicative of judgment of environmental issues and not of the actions of children and adolescents in the environment, since the judgment exerts influence, but does not determine their action.

Therefore, the answer to the research problem, that children and adolescents act to intensify or cause environmental problems, even if they are aware of the 
causes and consequences of environmental problems, is due to several factors: they do not attribute a value to the environment Sufficient to become aware of their actions, because of the level of knowledge and practice of autonomy, among other factors.

Environmental awareness involves coordination of logical operations, cooperation, moral judgment, and affection. Figure 5 seeks to exemplify how environmental awareness is constituted.

Finally, we emphasize that, in order to have an Environmental Moral Judgment in children and adolescents based on the intentions of their actions, in a respectful and subjective way, it is necessary that the school environment be cooperative, allowing them to exercise autonomy, development of affectivity and knowledge of environmental issues.

The practice of Environmental Education should promote activities that lead children and adolescents to reflect on moral dilemmas of local environmental problems through experiences with the use of concrete materials. Therefore, considering the environmental dimension in the Environmental Education proposal means explaining the changes in the environment, purpose and quantity of life in the short and long term. The use of the environmental dimension approach in Environmental Education proposals provides a breakthrough.

The greatest difficulty found in the study was to identify the types of knowledge and environmental judgment of children and adolescents.

We emphasize the need for future studies to analyze the interference of

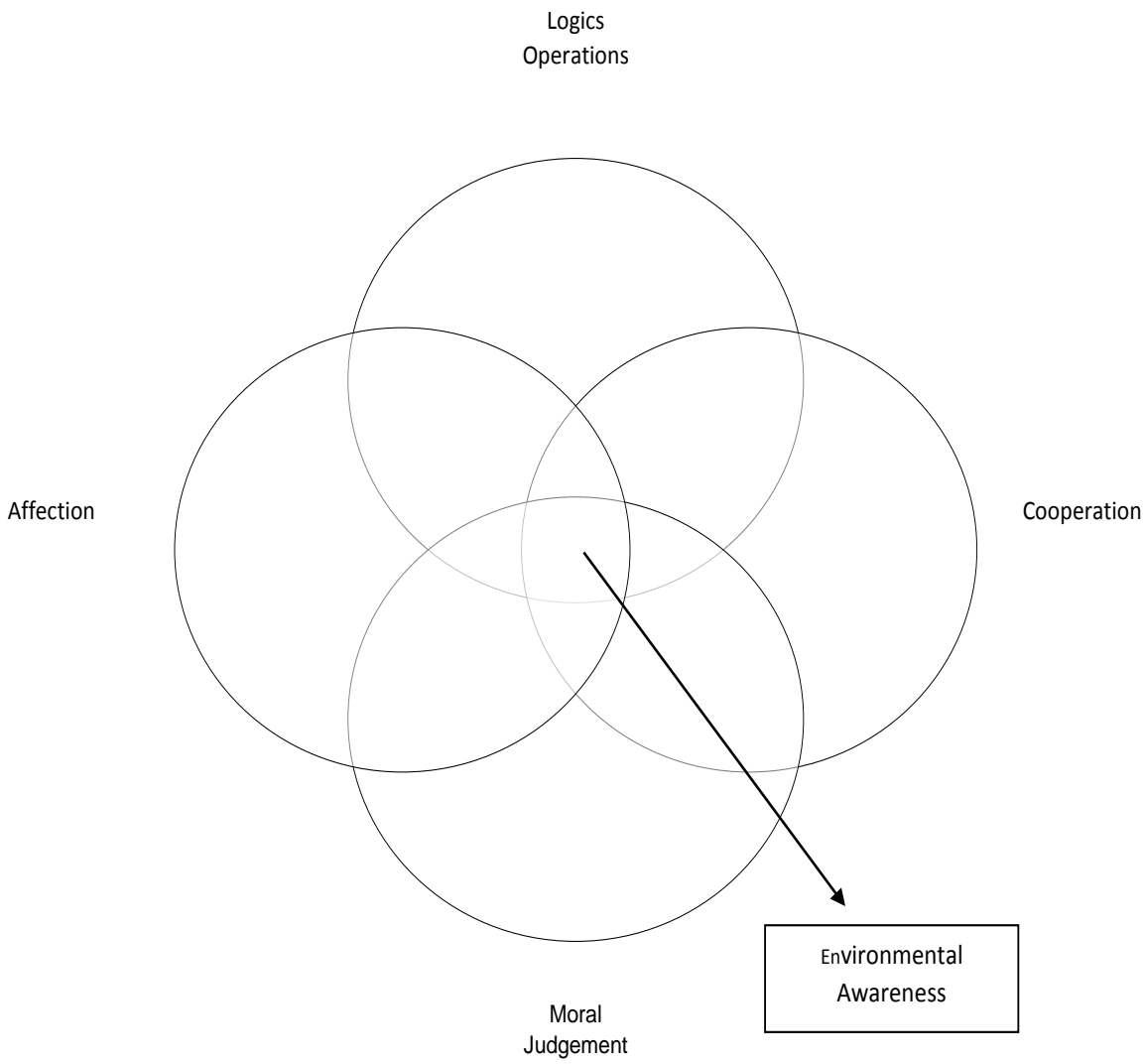

Figure 5. Environmental awareness. Source: Vestena (2011: p. 163). 
affectivity in the process of constitution of environmental moral judgment, as well as to evaluate the psychogenesis of environmental moral judgment.

\section{References}

Brailovsky, A. E. (1992). Esta, nuestra única Tierra: Introcción a la ecología y medio ambiente. Argentina: Ediciones Larousse Argentina.

Brasil. Lei n. 9795 de 27 de abril de 1999. (1999). Dispóe sobre a educação ambiental, institui a Política Nacional de Educação Ambiental e dá outras providências. Brasília: Diário Oficial da República Federativa do Brasil, n. 79, 28 abr.

Brasil. (2002). Decreto n. 4281 de 25 de junho de 2002. Regulamenta a Lei 9795 de 27 de abril de 1999 (...). Brasília: Diário Oficial da República Federativa do Brasil, n. 121, 26 jun.

Brasil. (2012). Ministério de Educação. Conselho Nacional de Educação. Resolução n. 2, de 15 de junho de 2012. Dispõe sobre as Diretrizes Curriculares Nacionais para a Educação Ambiental. Brasília, DF: D.O.U., 15 jun. Seção 1, p. 18.

Delval, J. (2002). Introdução à prática do método clínico: Descobrindo o pensamento das crianças. Porto Alegre: Artmed.

Organização Para Cooperação E Desenvolvimento Econômico (OCDE) (2009). Programa Internacional de Avaliação de Alunos-PISA. Brasília.

Parrat-Dayan, S. (2000). A Teoria de Piaget sobre a Causalidade. In M. Moreno, G. Sastre, M. Bovet, \& A. Leal (Eds.), Conhecimento E Mudança: Os Modelos Organizadores Na Construção Do Conhecimento (pp. 15-37). Campinas: Moderna.

Piaget, J. (1973). Estudos Sociológicos. São Paulo: Forense. (Études Sociologiques. Genève: Droz, 1965).

Piaget, J. (1977). O Julgamento Moral Na Criança. São Paulo: Mestre Jou. (Le Jugement Moral Chez L'enfant. Paris: F. Alcan, 1932).

Piaget, J. (1978). Fazer E Compreender. São Paulo: Melhoramentos (Réussir Comprendre. Paris: Puf. 1e Éd., 1974).

Piaget, J. (1979). A Noção De Tempo Na Criança. Rio De Janeiro: Editora Record. (Le Développement De La Notion De Temps Chez L'enfant. Paris: Presses Universitaires De France, 1946).

Piaget, P. (1983). A Psicologia Da Inteligência (2nd ed.). Rio De Janeiro: Zaha. (La Psychologie De L'intelligence. Paris: A. Collin, 1947).

Vestena, C. L. B. (2011). Piaget e a questão ambiental: Sujeito epistêmico, diagnóstico e considerações educacionais. São Paulo: Cultura Acadêmica. 
Submit or recommend next manuscript to SCIRP and we will provide best service for you:

Accepting pre-submission inquiries through Email, Facebook, LinkedIn, Twitter, etc. A wide selection of journals (inclusive of 9 subjects, more than 200 journals)

Providing 24-hour high-quality service

User-friendly online submission system

Fair and swift peer-review system

Efficient typesetting and proofreading procedure

Display of the result of downloads and visits, as well as the number of cited articles Maximum dissemination of your research work

Submit your manuscript at: http://papersubmission.scirp.org/

Or contact ce@scirp.org 